\title{
La naturaleza del intelecto humano en el De principiis de Orígenes de Alejandría
}

\author{
Manuel Correia \\ INSTITUTO DE FILOSOFÍA \\ PONTIFICIA UNIVERSIDAD CATÓLICA DE CHILE \\ mcorreia@uc.cl
}

\section{INTRODUCCIÓN}

En el De principiis de Orígenes de Alejandría el intelecto humano (mens en la traducción de Rufino y probablemente del griego nous en el original) es tratado, analizado y definido, en relación y correspondencia con todos los otros temas centrales que se mencionan en el texto: con las sustancias superiores (los principios) y con las sustancias inferiores (las cosas sensibles y sus elementos). Esta presencia implícita y explícita en todos los estratos del desarrollo de la obra, el cosmológico, el psicológico, el antropológico y el escatológico, habla de la importancia que tiene el intelecto humano en esta obra. Mi primera intención en este trabajo será, pues, poner de relieve esta noción al interior del De principiis. En esta obra, sin embargo, encontramos no solo un conjunto de creencias o afirmaciones sobre el intelecto humano, sino que un conjunto ordenado de afirmaciones sobre él, esto es, una teoría. En razón de esto, mi segunda intención es discutir si esta teoría es racionalmente aceptable, en particular, si todas las afirmaciones que el autor hace sobre el intelecto humano son consistentes entre sí, lo cual es una condición básica para que exista una teoría. Para cumplir estos dos objetivos, me basaré en un análisis del texto tratando de demostrar, lo más analíticamente que me sea posible, si el conjunto de afirmaciones sobre el intelecto humano es consistente y puede ser la base para una teoría o interpretación única sobre él ${ }^{1}$.

\footnotetext{
En lo que sigue, sin excepción, seguiré la traducción que Samuel Fernández me ha
} facilitado y que citaré conforme a la numeración de las páginas de su última versión 


\section{TeOrías y CONJUNTOS DE PROPOSICIONES: LA TEOlOGÍA DE ORÍGENES}

Antes de comenzar el estudio y análisis de la noción de intelecto humano en el De principiis, conviene destacar el carácter del trabajo teológico del autor desde un punto de vista lógico exclusivamente. La teología de Orígenes, como teoría, es una donde la razón natural (filosófica, científica y literaria) tiene un destacado lugar, porque busca la verdad a partir de la información que toma desde la interpretación de las Sagradas Escrituras y desde las conclusiones racionales que se pueden extraer de esta información, de modo tal que se forme un conjunto ordenado de conocimientos, un cuerpo orgánico verdadero. En esta definición, el autor se presenta como un teólogo científico en su proceder, aunque abriendo lugar a la discusión sobre la verdad o falsedad de algunas de las afirmaciones secundarias del cuerpo teórico. Este aspecto de su planteamiento hace del autor un teólogo que específicamente se caracteriza por buscar la consistencia del cuerpo teórico integrando la mayor cantidad de información en una interpretación de la verdad de las Sagradas Escrituras ${ }^{2}$.

"Así, pues, de acuerdo al mandato que dice: «lluminaos vosotros mismos con la luz del conocimiento», es necesario que estos como elementos y fundamentos sean utilizados por todo el que desea realizar, por medio de la razón, a partir de todos ellos, un cierto ordenamiento y conjunto orgánico; para que busque cuál es la verdad que está en cada una de las afirmaciones evidentes y necesarias; y constituya, como dijimos, un único conjunto orgánico, con ejemplos y afirmaciones, tanto con las <afirmaciones> que haya encontrado en las santas escrituras, como con las que haya descubierto a partir del examen de la misma concatenación lógica”. (I, 10, 4-12).

En efecto, en el De principiis, Orígenes de Alejandría hace una distinción metodológica entre lo que para nosotros sería un conjunto de pro-

provisoria. Orígenes de Alejandría. Sobre los principios I-II. Texto crítico, traducción y notas. Versión provisoria por Samuel Fernández. Santiago de Chile 2013.

2 Tal como S. Fernández comenta en su traducción (p. 33, nota 43): "Según Orígenes, la enseñanza cristiana puede ser estructurada en un conjunto racionalmente orgánico, en «un único cuerpo de la verdad» (Jn Com XIII, 303). Este «sistema» es elaborado sobre la base de dos elementos: la verdad de la Escritura (en oposición a su mera letra) y la concatenación lógica de estas verdades (akolouthia). El intento de sistematizar el contenido del evangelio de modo racionalmente orgánico parece ser una contribución origeniana que marcará el rumbo de la teología cristiana de modo irreversible". 
posiciones y una teoría. No propone esta distinción para un caso preciso, sino para toda su obra, sosteniendo en general que, quien quiera hacer un argumento y un cuerpo de doctrina sobre los elementos que él discutirá en su tratado, debe considerar racionalmente (ratione perficere) los elementos de juicio y los fundamentos que él ha dado sobre las afirmaciones y ejemplos de las Sagradas Escrituras. La confianza y apertura de Orígenes al saber de las ciencias y la literatura griega antiguas es tal que describe por sí misma la característica de su teología: científica, racional y abierta.

En mi opinión, merece hacerse la distinción de que su teología no es sistemática, si por sistemática se entiende la capacidad de una teoría de explicar por los mismos axiomas y reglas todas las afirmaciones de su sistema. En terminología de la lógica contemporánea, la teología de Orígenes debería ser denominada racional y científica, pero no sistemática, sino que -si fuera aceptable expresarnos con palabras peripatéticas, en este puntoes dialéctica, en el sentido de que permite la introducción de afirmaciones para ser examinadas e intentar responderlas (tractandi more ac requirendi discussa: Princ II, 8, 4). Estas afirmaciones dialécticas no vienen de la aplicación de la razón a las Sagradas Escrituras, no son doctrinas declaradas, como Orígenes dice (dogmata esse prolata, Princ II, 8, 4), sino que son tentativas y están en discusión para ser demostrativamente aceptadas.

Parece así que la teología de Orígenes no es sistemática, porque no es completa. Es consistente, extiende su cuerpo a través de relaciones demostrativas a partir de dos fuentes: las Sagradas Escrituras y la razón filosófica, científica y literaria (lo cual muestra un concepto amplio de razón). No muestra inconsistencias ni oposiciones (ni contrariedades ni contradicciones), pero permite que en algunos desarrollos haya indeterminación o falta de demostración. El caso de la teoría sobre el intelecto humano es un ejemplo: una vez que el autor tiene asentada por demostración la parte específica de la teoría, discute si tal otra afirmación (lógicamente esto puede significar actualmente otra teoría), que no había sido considerada antes, para saber si puede o no entregar una extensión a lo que ya está demostrado y aceptado. Pero la presenta hipotética o dialécticamente y nunca la discute sin la luz de las Sagradas Escrituras. La prueba de lo que digo es la misma expresión de su autor que solicita considerar la cuestión de si el intelecto humano (nous) se llama psyché o 'alma' después de la caída y que (siendo como es intelecto por naturaleza) se volverá a llamar intelecto, una vez salvado por Cristo, pues lo que 
estaba perdido, una vez que se encuentra y se pone a salvo, ya no se llama perdido (II, 8, 3). En razón de esto, Orígenes va a dar lugar a la opinión de "unos indagadores muy atentos" (II, 8, 3) que proponen que el alma viene de psykhros (frío), por razón de que el intelecto es como fuego y el alma no, sino fría como el viento Boreal (II, 8, 3). Como consecuencia, el intelecto enfriado es el alma. Entonces, como digo, para saber si esta afirmación (o bien esta 'teoría') no contradice lo que ya se tiene demostrado hay que examinar más y escrutar bien el sentido de las cosas, pues, tal como dice Orígenes en este punto: "En todo caso, no se debe pensar que [estas afirmaciones] sean como dogmas declarados por nosotros, sino cuestiones discutidas con el ánimo de examinar e investigar" (II, 8, $4)^{3}$. En esto no veo un defecto, sino una actualidad de su visión teológica. De hecho, este tipo de teorías son también mucho más interesantes y profundas, desde un punto de vista lógico, que un sistema formal.

Es por esta razón que cuando un tema como el del intelecto humano es tratado, es decir, la función más abstracta, exacta y universal del conocimiento humano (aquella que Platón, Aristóteles defendieron frente al escepticismo sofístico), el hecho de estar en posesión de afirmaciones referidas a su naturaleza, que son contradictorias o inconsistentes entre sí, es fatal no solo para una teoría del intelecto humano, sino también para tener una visión antropológica ejemplar. Sin embargo, si a un cuerpo teórico específico que no presenta problemas lógicos se le añade, de modo tentativo, alguna noción que no resulta cierta o que no puede demostrarse, no afectará intrínsecamente al cuerpo teórico, ni necesidad habrá de volver a revisar la parte específica y sana de la teoría.

El entendimiento humano en el De principis de Orígenes de AlejANDRía

En primer lugar, al comienzo del tratado, el autor sostiene una tesis general, sobre el intelecto humano. Tal tesis es tan general y comprensiva que hay que tomarla como la definición principal sobre el tema en cuestión:

3 En la nota 42, S. Fernández comenta lo siguiente: "Estas advertencias muestran que Orígenes es consciente, por una parte, del carácter hipotético de estas afirmaciones $y$, por otra, de que en su propio auditorio estas teorías tienen cierta resistencia. A propósito de Orígenes, Atanasio se refiere a este tipo de discurso como lo escrito por ejercicio (gymnazon egrapse) o lo dicho como por ejercitación (ta hos en gimnasia legomena). Cf. De decretis, 27, 1-2". 
(1) El entendimiento humano es la imagen intelectual de Dios (I, 1, 7), razón por la cual puede, por sus propias fuerzas, percibir (sentire) algo de la naturaleza de Dios, que es naturaleza intelectual simple $(I, 1,6)$. Precisamente es la conformidad o disconformidad de todas las afirmaciones que un autor hace sobre un tema en particular, tomado en sí mismo, lo que se debe examinar para saber si ellas forman (i) un conjunto ordenado y consistente, o bien (ii) un solo conjunto de afirmaciones consistente pero sin orden, o bien (iii) un conjunto inconsistente. Como hemos sugerido arriba, en los dos últimos casos no se puede hablar de una teoría sobre el objeto en cuestión. La definición dada en (1) por Orígenes es tan primitiva (desde un punto de vista lógico) que es muy improbable que no genere una teoría. Por lo tanto, las afirmaciones que Orígenes nos entrega en el De principiis sobre el intelecto humano probablemente formarán como en (i) una teoría, es decir, un conjunto de afirmaciones consistentes y que tienen un orden de secuencia lógica.

Y así es, porque, en concreto, la afirmación en (1) se condice lógicamente con la aseveración que dice:

(2) El entendimiento humano es inmaterial por naturaleza

Y con la afirmación subsiguiente que dice que:

(3) El entendimiento humano no necesita lugar para moverse

De este modo, discutiremos, en primer lugar, si estas tres afirmaciones, la definición general y las dos siguientes afirmaciones sobre el intelecto humano, son entre sí consistentes y forman un conjunto ordenado de afirmaciones o teoría. Para analizar esto, mostraré como justifica Orígenes las aserciones (2) y (3).

Según Orígenes, (2) es verdadera para la razón humana porque:

(2.1) A cada sentido corporal le está asignado un sensible correspondiente.

El argumento es claramente aristotélico o como se suele decir peripatético. Aristóteles en De anima había argumentado de la misma manera para mostrar que por naturaleza el sentido no se equivoca respecto de su sensible propio y es exacto en su conocimiento ${ }^{4}$. Esto significa que la vista no

4 Por ejemplo, De anima III, 425a30, 426b9-12. 
se equivoca respecto del color, ni el oído respecto del sonido y del mismo modo respecto de los otros sentidos y sus respectivos sensibles. Sobre la base de este argumento, Orígenes pregunta por qué el intelecto no debería tener un objeto apropiado a su actividad intelectual. De hecho, si no lo tuviera, el intelecto sería una actividad accidental en el hombre y derivada desde los cuerpos sensibles que los órganos de los sentidos externos conocen. Como conclusión, se seguiría que es lo mismo sentir que inteligir, lo cual es absurdo. De hecho, el tema filosófico del De anima, no es el 'yo', ni la unidad del intelecto, ni la inmortalidad del alma humana (porque Aristóteles es dicho haber dado estos argumentos de manera magnífica en el perdido escrito Eudemo), ${ }^{5}$ sino la distinción entre sentido e intelecto. Más bien, son los posteriores tratados sobre psicología y comentarios sobre el De anima los que tocan estos otros puntos. En consecuencia:

\section{(2.2) El intelecto no es accidental al hombre}

En el De Principiis existe un nuevo argumento para demostrar que el intelecto está en el ser humano, a saber, negar la realidad del intelecto en el ser humano significa que o bien se cree que Dios es un cuerpo o bien se cree que no hay Dios. Pero quienes dicen esto lo dicen sin pensar, porque el análisis racional nos lleva a la conclusión de que el intelecto humano y Dios están ciertamente emparentados como se dice en la definición (1), que destaca que el intelecto humano es la imagen intelectual de Dios, es decir, tal como Santo Tomás de Aquino luego iba a entender la expresión imago dei: la inteligencia humana es lo que mejor imita la naturaleza de Dios (S Th I, q. 93, a.4, c.).

En efecto, quienes creen que el intelecto no existe o que Dios es un cuerpo y no, como él lo afirma, la naturaleza intelectual simple (intellectualis natura simplex, Princ I, 1, 6), no atienden a las siguientes razones que demuestran definitivamente que el intelecto es inmaterial:

(2.3) El intelecto es inmaterial porque no requiere lugar para moverse

Esta frase nuevamente tiene consonancia peripatética. Según el reporte de Temistio en su paráfrasis al De anima de Aristóteles ${ }^{6}$, Teofrasto sostuvo que el intelecto es dicho ser pasivo o potencial, no en el sentido de ser

5 Themistius On Aristotle on the soul. Robert B. Todd (trad.), London 1996, p. 132. Ancient Commentators on Aristotle. R. Sorabji (ed.): Duckworth.

6 Temistio, On Aristotle on the soul, p. 133. 
móvil, porque el movimiento es imperfección, sino como una actividad pasiva, es decir, la de hacerse todas las cosas. En seguida, Orígenes agrega argumentativamente en la misma línea anterior que:

(2.4) Cuando actúa, el intelecto humano no aumenta ni disminuye su movilidad

Y lo dice así porque el lugar físico donde el intelecto actúa no tiene ninguna participación en la actividad intelectual. Parafraseando la idea de Orígenes, se puede agregar que el intelecto no es más ni menos exacto ni más ni menos abstracto, por causa de que el intelecto realice su actividad en tal o cual lugar de la Tierra. No obstante, Orígenes aquí se abre a una objeción: los zarandeados en el mar (I, 1, 6). Se sabe que la sacudida que produce el movimiento de las olas repercute en que no pensamos bien y a menudo los hombres se ven debilitados y enfermos por la agitación característica. A lo cual Orígenes responde que no es el intelecto el que se enferma o se mejora, sino el cuerpo es el que se ve afectado, el cual afecta de inmediato al alma. En efecto, "Por la enfermedad, el cuerpo, perturbado y confuso, no realiza su acostumbrado servicio a la mente en las condiciones habituales y naturales, puesto que nosotros, los hombres, somos un animal compuesto por el concurso de cuerpo y alma”. (I, $1,6,19-25)^{7}$. Y es que:

(2.5) La mente o intelecto está ligada e insertada al cuerpo.

En efecto,

(2.6) El hombre es un compuesto de alma y cuerpo.

Es igualmente consistente con lo anterior el que Orígenes, confirmando la inmaterialidad del intelecto humano, nos diga que este para realizar su actividad característica no requiere de fuerza corporal. Lo dice en el sentido filosófico de la expresión, es decir, es falso que los hombres más fuertes al mismo tiempo y por la misma razón sean los mejores razonadores. De nuevo, en el argumento resuena un son peripatético, ya que inmediatamente Orígenes dice que con los sentidos corporales sí ocurre

7 En la versión de S. Fernández se traduce “(...) somos un animal compuesto por el compuesto de cuerpo y alma" (nos homines animal sumus compositum ex corporis animaeque concursu). He modificado levemente la traducción traduciendo concursu por concurso. 
así, es decir, requieren de magnitud corporal para moverse. En el De anima, como ya dijimos, Aristóteles establece la naturaleza del intelecto humano en una sistemática comparación con los sentidos corporales y por eso sostiene que el intelecto, a diferencia de los sentidos corporales, no se fatiga con la presencia de su objeto propio. En efecto, mirar el sol o un fuerte ruido produce una saturación y fatiga momentáneas del sentido corporal, pero el intelecto no se ve reaccionar así ante los inteligibles y universales ${ }^{8}$. Es por esta razón que Orígenes sostiene que:

(2.7) El intelecto humano no requiere de magnitud corporal para realizar algo o moverse como los órganos de los sentidos.

Lo que requiere sí el intelecto humano, agrega el autor, es magnitud intelectual (magnitudine intelligibili, I, 1, 6) para agudizar su perspicacia (acumen ingenii), lo cual se obtiene a través de la ejercitación del estudio (eruditionis exercitiis). Y es que en la medida de que el cuerpo madura, el intelecto es más capaz de realizar avances tales como acoger una disciplina y tener más fortaleza para actuar.

Es pues muy claro en esta argumentación que nos entrega Orígenes en su tratado De principiis, que el intelecto humano actúa de la manera que tiene que actuar conforme a su naturaleza, con independencia del cuerpo, pero la calidad de aquel se ve mejor expresada conforme al estado del cuerpo y del alma que lo anima (si está perturbado o no, por ejemplo por la fiebre, o si está entrenado o no, por ejemplo, por la aplicación a los estudios).

\section{LAS PRUEBAS POR ABSURDO}

Que Orígenes está adiestrado en filosofía griega y en particular que conoce la manera de argumentar que los peripatéticos ocupan en su discusión sobre la naturaleza del intelecto humano, se aprecia porque a continuación Orígenes presenta argumentos por absurdo que resultan totalmente demostrativos para el punto que quiere probar, a saber, la inmaterialidad del intelecto humano. Como es sabido, en la demostración por absurdo ponemos en duda la conclusión del razonamiento y la unimos a las premisas aceptadas. La nueva conclusión resulta ser inconsistente con lo que ya teníamos aceptado. En el caso particular,

8 Cf. Aristóteles De anima 429b1. 
preguntamos ¿̨uede el intelecto humano ser una sustancia corpórea? La respuesta es categórica: No; y las razones son las siguientes:

(2.8) Porque el intelecto humano es capaz de contener un sinnúmero de proposiciones y argumentos sobre las cosas en general (I, 1,)

Además, ya que hay inteligibles (asunto que un filósofo como Platón y Aristóteles no discuten ni niegan).

(2.9) No podríamos memorizar ni contemplar inteligibles si el intelecto fuera material.

Además,

(2.10) Lo corpóreo no puede examinar lo que es de naturaleza incorpórea

Acota Orígenes que es igualmente absurdo tener que concluir que no habría forma de entender los dogmas divinos (divina dogmata: I, 1, 7), que son espirituales, por causa de que el intelecto humano dependiera del cuerpo o fuera un órgano corporal, ya que de hecho existe esta comprensión intelectual de los dogmas divinos. Por lo demás, si el intelecto humano fuera corporal ¿de qué color sería?? Y es que, en efecto, como Aristóteles, Platón y todos los filósofos griegos lo aceptaban, todo lo corporal tiene un color. ¿No es acaso que el mismo Aristóteles en De anima pregunta qué características físicas tendría el intelecto si fuera corporal? (De anima 429a25): "Por esta razón, no sería razonable considerar que el intelecto está mezclado con el cuerpo: si fuera así, poseería alguna cualidad, por ejemplo, caliente o frío, o incluso tendría un órgano como la facultad sensitiva; pero en verdad no lo tiene" ${ }^{10}$.

SUMARIO DE LA DISCUSIÓN SOBRE LA INMATERIALIDAD DEL INTELECTO HUMANO: ¿ES COHERENTE LA INTERPRETACIÓN QUE EL AUTOR HACE DEL INTELECTO HUMANO?

Hemos analizado si la noción de intelecto humano que el autor tiene es consistente. Sostiene el autor que el intelecto humano es absolutamente inmaterial, pero su noción no es simple, como la de Dios, ya que está

De principiis I, 1, 7, 33-34.

10 Las traducciones desde el griego del De anima de Aristóteles son mías. Las traducciones de Temisto las tomo de Todd (1996). 
determinado a existir en un alma que anima un cuerpo. El intelecto divino, en contraste, no está ligado ni insertado, sino que define la actividad de Dios, quien es "naturaleza intelectual simple" (I, 1, 6), absolutamente monádico y henádico (I, 1, 6, 8-10).

A continuación, se han discutido las razones que el autor da para afirmar que el intelecto humano es inmaterial, su actividad no ocupa lugar y no sufre ni se ve afectado ni menos imposibilitado en sí mismo por las circunstancias y estímulos que afectan al alma a través de afección que los órganos del cuerpo a su vez experimentan, sino que lo que se ve afectado es el hombre, su alma y su cuerpo, como cuando el instrumento que usamos para hacer algo está deteriorado o defectuoso. Y es que Orígenes ha dicho que se trata de un intelecto insertado en el alma y cuerpo humanos. El hombre es en efecto "el compuesto de cuerpo y alma".

Hemos hecho ver que en el planteamiento del tema del intelecto humano, en particular en las razones que usa Orígenes para justificar racionalmente sus afirmaciones, se revela un conocimiento del marco de discusión filosófica sobre el alma y el intelecto humanos, en especial de raigambre peripatética, pero que esta familiaridad textual de ninguna manera se puede entender como una dependencia textual ni doctrinal de Aristóteles o de autores peripatéticos posteriores.

\section{LA RELACiÓN DEL INTELECTO HUMANO CON EL COMPUESTO DE ALMA Y CUERPO}

La naturaleza inmaterial del intelecto humano trae a cuestión la relación que guarda este con el alma y con el cuerpo. Sostener como sostiene Orígenes en De principiis que el intelecto no es el que se ve entorpecido por las circunstancias materiales que afectan al cuerpo y al alma no es suficiente para establecer su relación. Sin embargo, como voy a exponer ahora, sería un error creer que Orígenes ignora o no ve el punto. Según voy a mostrar ahora, Orígenes es consciente de ambas cosas: que hay que resolver definitivamente el problema filosófico de la relación entre el intelecto humano y el alma y que la discusión peripatética que hay a la sazón sobre este tema es compleja y aporética.

En las páginas que Teofrasto dedicó al tema de la relación del alma con el intelecto y que Temistio transmitió en su Paráfrasis sobre el De 
anima de Aristóteles ${ }^{11}$, se nota una intrincada discusión sobre la relación de los dos intelectos, el activo y el pasivo que Aristóteles distingue en $D e$ anima III, cap. 5. Teofrasto no está comentando a Aristóteles solamente; según su costumbre, va más allá que él y pregunta cómo es posible que el intelecto humano viniendo desde fuera (porque es separado), y como si fuera agregado, puede ser, natural y espontáneamente, afín con el cuerpo (Temistio, p. 133). Su respuesta -que Temistio la extiende a Aristóteles y así a toda la escuela peripatética (pues se refiere a ellos, i.e., a Aristóteles y Teofrasto)-, es que el intelecto pasivo es inseparable del cuerpo, lo cual explica la alteración o modificación psicológica que afecta al hombre que razona y por qué ocurre el olvido la falsedad y la confusión, mientras que el otro, el activo, que es 'como una mezcla del intelecto pasivo y el activo', es puesto separado del cuerpo, incorruptible e increado. Según reporta Temistio (p. 134), estos intelectos, el pasivo y el activo, son naturalezas que de manera diferente son una y dos, porque todo lo que es combinado de materia y forma es uno ${ }^{12}$.

La idea de que los dos intelectos el pasivo y el activo están conectados por medio de un vínculo mortal, que son las pasiones racionales, es para Temistio (p. 132) una doctrina que Aristóteles toma del Timeo de Platón ${ }^{13}$. Temistio cita el pasaje completo así (destacado nuestro):

"When they had taken over an immortal principle of soul, they next
fashioned for it a mortal body by framing a globe around it, building
on another kind of soul that was mortal, and that had in itself terri-
ble and necessary affections: first, pleasure, the strongest lure of evil;
next, pains that flee from good; and also boldness and fear, two foo-
lish counselors; spirit hard to entreat, and hope too easily led astral.
These they blended together with irrational sense and desire that
shrinks from no venture, and so compounded the mortal part of the

11 Temistio (1996).

12 Temistio 108, 28 (=p. 134). "From all this it is clear that we are not inappropriately assuming that one intellect is passive and perishable, which <Theophrastus and Aristotle $>$ also call 'common' and 'inseparable from the body' (it is mixture with this <intellect $>$ that Theophrastus says causes loss of memory and confusion $<$ from the productive intellect $>$ ); and another <intellect $>$ is like a combination from the potential and actual <intellects>, which they posit as separate from the body, imperishable, and uncreated. These intellects are natures that in different ways are one as well as two, for what <is combined > from matter and form is one".

13 Temistio cita el pasaje en su Paráfrasis y R. Todd (el editor de la Paráfrasis para la serie Ancient Commentators of Aristotle) cita el 69c5-e4. 
soul. And in awe of polluting the divine part on account of all these, except insofar as was altogether necessary, they housed the mortal part apart from it (...)"

Y es que según Temistio Platón cree que mientras el intelecto activo es él solo inmortal, tal como Aristóteles luego dice en De anima 430a23, las afecciones y la razón presentes en ellas (que Aristóteles llama intelecto pasivo) son corruptibles (Temistio p. 132). Esto es, por lo demás, explica Temistio aquí mismo, lo que distingue al animal racional del irracional, porque mientras el irracional no tiene afecciones racionales no puede ser virtuoso, mientras que en el caso del animal racional las afecciones sí son sensibles al intelecto, de modo que cuando son moderadas llegan a ser virtudes. Esta es la razón por la cual Temistio cree conveniente citar al estoico Zenón, quien no malamente habría dicho que las afecciones del alma humana son 'perversiones de la razón', o sea juicios erróneos del intelecto ${ }^{14}$.

A la luz de la información que entrega Temistio en su Paráfrasis sobre el De anima de Aristóteles, no sería justo exagerar o afirmar sin condiciones la influencia de la escuela peripatética en los autores del siglo III y IV de nuestra era (para no nombrar a los autores neoplatónicos de los siglos siguientes), sino la influencia de la unión doctrinal entre la escuela platónica y peripatética que no solo Temistio, sino que Porfirio y todos los neoplatónicos creyeron que confluían en una única y misma verdad. En el caso particular aquí, el Timeo y el Fedón (porque Temistio dice que todos los argumentos que prueban la inmortalidad del alma humana dados por Platón aquí se refieren no al alma sino al intelecto humano, cf. p. 132 $)^{15}$ son una parte importante en la exégesis y comentario del $D e$ anima de Aristóteles y las enseñanzas correspondientes agregadas luego por Teofrasto.

De hecho, Orígenes concuerda con las siguientes tesis que pueden ser de alguna manera rastreadas en la tradición peripatética que el mismo Temistio acepta y tal vez adopta de Alejandro de Afrodisia en su comentario al De anima de Aristóteles, texto que es descrito por Temistio

14 Temistio 107,4 y ss. "Seno $<$ the Stoic $>$ and his school were not wrong in taking the affections of the human soul to be 'perversions of reason', i.e. mistaken judgments of reason".

15 Temistio 106, 29. And most of the weightiest arguments concerning the immortality of the soul that Plato propounded essentially refer back to the intellect (...)". 
como de larga extensión y así probablemente de carácter enciclopédico, como suelen ser los comentarios de Alejandro a las grandes obras de Aristóteles: ${ }^{16}$ (i) El intelecto es inmaterial y viene desde fuera (o es separado). (ii) El hombre no es su alma sino que el compuesto de alma y de cuerpo. (iii) El alma es una sustancia phantastike y hormetiké (perceptiva y móvil) ${ }^{17}$. (iv) El intelecto se une con el intelecto común o pasivo a través de un vínculo corruptible, porque lo inmortal e inmaterial no puede actuar directamente sobre lo material y así es necesario la mezcla y el intermedio proporcionado.

Orígenes discute algunas diferencias en la comprensión de estas relaciones y justifica racionalmente la confirmación de estos principios. Y aunque no utiliza la distinción hilemórfica para el análisis del intelecto humano, parece plausible creer que la doctrina general que Orígenes desarrolla en el De principiis es tributaria del análisis sobre el intelecto humano hecho por Aristóteles en De anima y los peripatéticos y neoplatónicos posteriores (probablemente el mismo comentario al De anima de Alejandro de Afrodisias que se admite ser la base de la paráfrasis de Temistio, ya que este menciona el trabajo anterior de Alejandro y se han detectado dependencias literales de Temistio sobre Alejandro).

16 Al comienzo de su paráfrasis sobre el De Anima de Aristóteles, Temistio recuerda el comentario de Alejandro, y si bien no dice estar siguiéndolo, reconoce su amplia extensión. Temistio es posterior a Orígenes de Alejandría, pero si Temistio ha confiado sus enseñanzas al mismo De anima de Aristóteles y a su tradición de comentarios, entonces muchas de las familiaridades doctrinales entre ambos se pueden deber a la dependencia que los tratadistas y comentaristas sobre el De anima tuvieron del comentario de Alejandro de Afrodisias a este tratado. En efecto, Temistio dice $(1,2)$ : In this treatise we must try to follow Aristotle on everything that can be systematically understood about the soul, and to elucidate, reconstruct, and analyse some <issues>, and (if it is not tactless to say so) even fully elaborate still others. The treatise $O n$ the soul in fact merits more respect than all of Aristotle's numerous and remarkable compositions for the quantity of problems that his predecessors had not even managed to enumerate, for the ease with which he endowed the investigation of them, as will be clear from what we shall actually say".

17 Aunque sobre esta definición de alma no hemos comentado nada en este trabajo, su conexión con la doctrina peripatética es evidente también en Temistio: En 116, 26 (y comentando De anima 432a 15-22) Temistio dice: "The soul of animals is defined above all by the capacity for discrimination (the function of discursive thinking and sense-perception), and by the capacity for causing movement in respect of place". 
Y si bien lo que decimos es plausible, hay una afirmación o una teoría en el De principiis que citamos al comienzo del trabajo, aunque en forma resumida, que parece poner en riesgo no solo la plausible relación de la teoría del intelecto humano con bases peripatéticas sino la misma consistencia de su teoría del intelecto humano. En efecto, en De principiis II, 8, donde se encuentra un breve tratado en el que se propone "investigar sobre el alma en general”, Orígenes de un modo dialéctico desarrolla la discusión de si es posible pensar que el intelecto, que como sabemos es puesto desde fuera, se transforma y confunde en un cierto grado con el alma según se enfría su ardor y perspicacia por las cosas divinas que son como fuego. En efecto, cómo conciliar las afirmaciones anteriores (1) a (3) con la siguiente que dice:

(3) El intelecto <con la caída> se transforma en alma (II, 8, 4: diximus mentem in animam vertit)

¿Puede el conjunto de las proposiciones (1) a (3) ser consistente y, por tanto, entrañar una conclusión que permita a este conjunto de creencias tener una única interpretación sobre el entendimiento humano? Esta es la cuestión que nos hemos propuesto resolver analíticamente. Y hay que hacer un último esfuerzo por conciliar las partes, si esto es posible.

\section{EL ALMA ES UN INTELECTO ENFRIADO}

Los capítulos finales de De principiis II, 8 se inclinan hacia la tesis de que el alma humana cuando haya alcanzado la bienaventuranza salvadora ya no será llamada alma, sino que será denominada conforme a su naturaleza primitiva: nous, intelecto. Razón por la cual, Orígenes cree que hay que resolver también el siguiente problema:

"Pero tal vez se deba investigar <lo siguiente>: si es la mente <i.e., el intelecto $>$ la que ora y salmodia con el Espíritu, y es ella misma la que alcanza la perfección y la salvación, ¿̨por qué Pedro dice (1Pe 1, 9): 'Alcanzando la perfección de nuestra fe: la salvación de nuestras almas?' Si el alma con el Espíritu ni ora ni salmodia, ¿̇de qué manera esperará la salvación?, ¿o acaso cuando haya alcanzado la bienaventuranza ya no será llamada alma?" (De principiis II, 8, 3)

Lo que Orígenes vierte aquí es la cuestión de cuál es la parte anímica que alcanza la salvación, si el solo intelecto -como dirían los teólogos influidos por la doctrina peripatética- o si también el alma humana. Y así Orígenes se aprecia profundo y amplio al unir la filosofía con las 
Sagradas Escrituras, es decir, al relacionar la discusión filosófica sobre la separabilidad del entendimiento humano en el De anima de Aristóteles y la salvación del alma humana en el versículo bíblico (1Pe 1, 9). En efecto, no solo hay que explicar ahora cómo lo que es inmaterial y no ocupa un lugar pueda entrar en contacto con algo material, sino que también por qué Pedro habla de la salvación de nuestras almas.

De un modo resumido, argumentaré ahora que Orígenes cree que las proposiciones (1) a (3) son perfectamente consistentes y que (3) busca resolver el problema de la relación entre el alma y el intelecto, es decir, el problema de la relación de los dos intelectos que distingue la escuela peripatética. De este modo, creo ver finalmente en Orígenes una muy interesante y profunda solución al problema de la interacción entre el intelecto y el alma, de la relación o participación de lo material con lo inmaterial.

Según Orígenes, "parece que se puede demostrar que el intelecto, decayendo de su estado y dignidad, se volvió o comenzó a ser llamada 'alma', la que si fuera renovada y corregida, vuelve a ser nous, es decir, intelecto" (II, 8, 3). Y es que como ya veíamos, "así, tal vez, también lo que es salvado se llama alma, pero cuando ya haya sido salvada, será llamada con el nombre de su parte más perfecta” (p. 331).

La doctrina de que el alma humana es un intelecto que ha llegado a ser alma es la doctrina que sostiene que el intelecto es la verdadera sustancia que viene desde fuera, increada para los peripatéticos, creada para Platón, los neoplatónicos y las Sagradas Escrituras. Viene de afuera, creada por Dios, y recibe el embate de la naturaleza al experimentar la caída. El alma es así un espíritu anquilosado, para Orígenes, de modo que no hay ninguna separación entre alma e intelecto, sino que el intelecto llega a ser alma en la medida de que se relaciona y mezcla con la naturaleza creada. Pero ¿se conserva el intelecto? ¿O se hunde enteramente y se confunde enteramente con la naturaleza de modo que adquiere los vínculos de las afecciones y los determinismos naturales tergiversando su naturaleza primitiva?

Para aclarar estas dudas, Orígenes echa mano a una metáfora aprovechando el ingenio de unos "indagadores muy atentos" (requirentibus curiosius) que avanzaron una interpretación para nada despreciable (II, $8,3)$. Dios es fuego, los ángeles son descritos así también como luminosos y fervorosos. Se nos recomienda ser ardientes en espíritu y el 
mismo Cristo dice (Mt 24, 12) "Porque se ha multiplicado la iniquidad, se enfriará la caridad de muchos". En consecuencia, concluyen estos escrutadores, el logos de Dios es fuego. De aquí que no es un error sostener como han sostenido estos indagadores atentos, que la palabra psyché proviene de psykhros (enfriamiento) y que el nombre de 'alma' describe el proceso por medio del cual el intelecto se instala en el hombre como una realidad anímica, conservando en algunos casos un mayor ardor y en otros casos uno menor. Por esta razón, el pecado termina por enfriar el intelecto y convertir al ser humano en la sola pulsión natural y determinada, enfriando la caridad, la espiritualidad propia del intelecto y su separación de lo corporal. De este modo, la cuestión de cómo se relaciona lo inmaterial con lo material queda resuelta en principio: lo inmaterial es lo puro, lo que no se mezcla con la materia que fue necesaria por la caída de los intelectos.

La cuestión de quiénes son estos indagadores muy atentos es un puzzle muy difícil de resolver. En los comentarios y notas de Crouzel y Simonetti al De principiis (Sources Chretiennes), se cita a distintos autores en quienes se relaciona la idea de que el alma humana, la psyché deriva semánticamente de psykhros. Platón en Cratilo 399d. El mismo Aristóteles en De anima 405b dice que algunos hacen esta derivación notando que el enfriamiento causado por la respiración da vida al cuerpo animal ${ }^{18}$. Pero que estos autores sean los indagadores atentos parece improbable, porque lo que dice Orígenes es que estos indagadores partiendo de esta asociación léxica alcanzaron esta teoría según la cual el alma, la naturaleza creada corporal y el pecado logran enfriar el intelecto que es como fuego conforme a su mismo origen. Además, mencionan las Sagradas Escrituras en apoyo textual.

Es por esta razón que más cercanos son autores como Juvenal (no citado por Crouzel y Simonetti) quien en su Sátiras I, 165-167, dice que aquel "tiene el alma helada por sus crímenes", ya que Juvenal da con el pensamiento establecido por el Señor Jesucristo cuando dice "Porque se ha multiplicado la iniquidad, se enfriará la caridad de muchos", pero aún así es insuficiente como fuente.

18 El mismo Temistio cita esta creencia en su Paráfrasis $(14,14)$, en referencia al texto del De anima de Aristóteles (405b23-29). 
Pero que Juvenal sea la fuente de estos indagadores atentos es improbable. La única de todas las fuentes que Crouzel y Simonetti han consignado en esta nota al texto de Orígenes (cf. p. 204) y que parece dar por completo el sentido de la teoría que Orígenes está proponiendo para superar definitivamente el problema de la relación de lo inmaterial con lo material es aquella que refiere al De anima de Tertuliano (25, 6 y 27,5$)$, donde se compara el proceso mencionado por Orígenes con la introducción de un hierro incandescente en el agua. Al hacerlo así se explica perfectamente la idea que quiere Orígenes obtener, a saber, que la mayor o menor porción de intelecto en un hombre es proporcional a su ardor espiritual por Dios y las cosas divinas "y por este motivo, algunos, desde que alcanzan la edad, se encuentran con una inteligencia más ardiente, otros con una más torpe y otros nacen muy obtusos y totalmente incapaces de aprender" (II, 8, 4). En efecto, la imagen del hierro de Tertuliano muestra que el hierro incandescente no produce un problema de comunicación entre su parte encendida y su parte enfriada, porque su sustancia es una y la misma. No obstante, no parece tampoco plausible que haya sido directamente Tertuliano quien haya influido en Orígenes, aunque el que Tertuliano termine este pasaje del hierro incandescente diciendo que esto se ve en Enesidemo y en Numenio de Apamea abre una posibilidad de que hayan sido estos autores o discípulos de su entorno los que hayan inspirado a estos indagadores muy atentos, quienes por lo demás parecen más bien cercanos a Orígenes y a las Sagradas Escrituras.

Quienes sean estos indagadores muy atentos, lo cierto es que su comentario parece haber inspirado uno de los pasajes más interesantes de la historia de la psicología y de la antropología. Tal como entiendo este asunto, Orígenes parece estar insinuando hacia el final del II, 8, no solo que entre las proposiciones (1) a (3) no hay ninguna inconsistencia, sino que además la afirmación de (3) contiene la solución al problema de la participación y la comunicación de lo material y lo inmaterial. Participar según Platón es un término central para la filosofía pero tiene muchas explicaciones. Se puede entender como se entiende en Fedón y República. O como en el Banquete. O como en el Sofista y el Político. Aristóteles también dice en Metafísica XII que finalmente se ha aclarado que significa participación cuando sostiene que el motor inmóvil es a la vez el bien y el orden en el universo y el cielo y a la vez el principio del bien y el orden. Es por esto que lo que Orígenes dice en De principiis 
sobre el intelecto es muy interesante y central para esta misma discusión, pues para responder a la cuestión de cómo se relaciona lo inmaterial del intelecto con la materialidad del alma humana, este autor ha dicho que el alma humana es un intelecto enfriado, o sea un intelecto que llega a ser alma y que se reconvertirá en intelecto cuando haya sido salvada, "pues liberada nuevamente de la perdición, puede ser otra vez aquello que fue antes de que pereciera y fuese llamada alma”. (II, 8, 3)

\section{BiBLIOGRAFÍA}

Themistius On Aristotle on the soul. Robert B. Todd (trad.), London 1996. En: Ancient Commentators on Aristotle. R. Sorabji (ed.), London 1996: Duckworth.

Orígenes de Alejandría, Sobre los principios I - II. Texto crítico, traducción y notas por Samuel Fernández. Versión provisoria. Sin publicar.

Origène. Traté des Principes (I et II). H. Crouzel et M. Simonetti. 2 vols. Paris 1978. Sources Chrétiennes: Les Éditions du Cerf.

Aristóteles De anima. Ross, W. D., 1961. edited, with introduction and commentary, Oxford: Clarendon Press.

Aristóteles, The complete works of Aristotle. The revised Oxford translation. J. Barnes (ed.). vol. 1. Princeton 1984. Bollingen Series: Princeton Univ. Press. 
Resumen: En este artículo se revisa críticamente la teoría sobre el intelecto humano que Orígenes de Alejandría mantiene en su Tratado sobre los Principios. En esta revisión se aprecia una importante influencia del comentario peripatético sobre el alma humana sin que haya una dependencia de Orígenes sobre esta literatura. Más bien, se da una reflexión original cuyo objetivo es resolver el problema de la participación del intelecto separado con el alma y el cuerpo humanos. La solución es notablemente efectiva y se consigue incorporando el punto de vista de autores de su tiempo quienes sostienen, conforme a lo que dicen las Sagradas escrituras, que el alma humana es un intelecto enfriado por la caída y contacto con la naturaleza creada.

Palabras clave: Intelecto, alma, cuerpo, sensación, participación.

Abstract: In this article the theory of human intellect maintained by Origen of Alexandria in his treatise On First Principles is critically revised. It is appreciated an important influence of Peripatetic commentary on human soul but without existing a dependence of Origen on this literature. Rather, Origen presents an original reflection whose aim seems to be to resolve the problem of how the intellect participates with the soul and human body. The solution is notoriously effective and it is reached by involving the viewpoint of some authors of his time maintaining, in accordance with Holly Scriptures, that human soul is an intellect chilled by fall of souls and their contact with the created nature.

Keywords: Intellect, soul, body, sensation, participation. 
